\title{
Evaluation on Maturity Assessment System of Government Internal Control System (SPIP) in Local Government
}

\author{
Mukhlis*, Sumirah" and Adhitya Latif Prahesta \\ *Gadjah Mada University \\ Economics and Business Department of Vocational School \\ Prof. Notonegoro Street, Bulaksumur, Yogyakarta, 55281, Indonesia \\ E-mail: mukhlis_ginting@mail.ugm.ac.id \\ \# Gadjah Mada University \\ Economics and Business Department of Vocational School \\ Prof. Notonegoro Street, Bulaksumur, Yogyakarta, 55281, Indonesia
}

\begin{abstract}
The purpose of this research is to identify problems existing in the maturity assessment system of Government Internal Control System (SPIP) based on the Regulation of the Head of Finance and Development Supervisory Agency (BPKP) Number 4 of 2016 and provide the solutions. The research method was qualitative, using primary data through interview and focus group discussion. Secondary data were in the form of laws and regulations, guidelines, as well as maturity assessment instrument for SPIP. The data analysis used an interactive model. This research found that the current assessment system did not direct the assessment team and quality assurance team to perform an analysis of relationship among SPIP indicators and between SPIP indicators and other governance indicators. In addition, the scoring system is considered to be emphasized more on the fulfillment of administrative evidence rather than the substance of the assessment. Therefore, the assessment system should consider the relationship of variables in the assessment process and put forward the substance of the assessment rather than the completeness of documentation.
\end{abstract}

Keywords: SPIP, control, measurement, maturity 


\section{Introduction}

The government attempts to improve the effectiveness and efficiency, as well as the governance by issuing the Government Regulation Number 60 of 2008 on Government Internal Control System (SPIP). The Government Regulation No. 60 of 2008 set out more specific goals, that is improving the effectiveness and efficiency of the state administration, safeguarding the state assets, improving the reliability of financial statements, and improving the compliance of the State administrative officials with the applicable legislation. To support the implementation of SPIP, the Government has set a specific target in the Medium-Term National Development Plan (RPJMN) Year 2015-2019 and Year 2020-2024 on the score of 3 from a scale of 0-5. To assess the achievement, the Government appointed the Finance and Development Supervisory Agency (BPKP) to conduct an assessment on the maturity of SPIP.

Definition and scope of Government Internal Control System (SPIP) is stipulated in Government Regulation No. 60 of 2008 on SPIP (PP No. 60 2008). PP No. 60 of 2008 Article 1 point 2 states: "Government Internal Control System (SPIP), hereinafter referred to as SPIP, means the Internal Control System conducted comprehensively both in central and local governments". SPIP consists of five elements; (1) control environment, (2) risk assessment (3) control activities (4) information and communication, (5) internal control monitoring. The implementation of the five elements provides reasonable assurance in attainment of the effectiveness and efficiency of the achievement of the government administration objectives, the reliability of the financial statements, the safeguarding of the state asset, and the compliance with the legislation.

All government agencies must apply SPIP at least due to three aspects (Mukhlis, 2018). First, the government rules which requires its implementation. It is contained in Government Regulation (PP) 60 of 2008 Article 1 point 2 that SPIP is conducted comprehensively both by central and local governments. Second, the implementation of SPIP helps the government agencies achieve the goals of organization. Third, amendment of the laws and regulations and management environment requires risk mitigation that can be managed with the implementation of SPIP.

To support the improvement of SPIP implementation, the government sets a target level of maturity and conducts an assessment of the achievement on all ministries, agencies, and local governments (M/A/L). The target level of maturity is determined to reach level 3 of the scale of 0-5. This target is contained in RPJMN Year 2015-2019 and RPJMN Year 2020-2024. The assessment of the maturity of SPIP is conducted by BPKP as the supervisory apparatus for SPIP implementation as defined in PP No. 60 of 2008. BPKP has started to conduct the maturity assessment of SPIP since 2016.

BPKP conducts a maturity assessment on SPIP using assessment instruments compiled in the Regulation of the Head (Perka) BPKP No. 4 of 2016 on Assessment Guideline and Strategy of Maturity Improvement of Government Internal Control System. The maturity level is divided into six, starting from 0 to 5 with the characteristics as presented in Table I.

TABLE I.

SCORE INTERVAL OF SPIP MATURITY LEVEL

\begin{tabular}{|c|l|l|}
\hline Level & \multicolumn{1}{|c|}{$\begin{array}{c}\text { Maturity } \\
\text { Level }\end{array}$} & \multicolumn{1}{c|}{ Score Interval } \\
\hline 0 & Not available & Less than $1.0(0<$ score $<1.0)$ \\
\hline 1 & Pioneering & 1.0 to less than $2.0(1.0 \leq$ score $<2.0)$ \\
\hline 2 & Developing & 2.0 to less than $3.0(2.0 \leq$ score $<3.0)$ \\
\hline 3 & Defined & 3.0 to less than $4.0(3.0 \leq$ score $<4.0)$ \\
\hline 4 & $\begin{array}{l}\text { Managed and } \\
\text { measurable }\end{array}$ & 4.0 to less than $4.5(4.0 \leq$ score $<4.5)$ \\
\hline 5 & Optimum & Between 4.5 to $5.0(4.5 \leq$ score $\leq 5)$ \\
\hline
\end{tabular}

Source: Regulation of the Head of BPKP Number 4 of 2016

Maturity assessment that has been conducted by BPKP causes dissatisfaction on the assessed agencies. Based on the interview with inspectorate auditor on one of the government district in the Province of Special Region (DIY) of Yogyakarta, it is obtained information that there are two problems or dissatisfaction on the SPIP maturity assessment. First, the lack of documentation resulted in the assessment results lower than it should be. For example, the local government has set a policy/rule/SOP (level 1) and has been running the policy/rule/SOP (level 3) but they do not have documentation of the promotion activities (level 2). The final result of this assessment is level 2 because it is considered impossible that a policy can be implemented if it is not properly promoted. Second, digital authorization is still debatable for its validity in the process of SPIP maturity assessment. For instance, the local government has built an online financial information system which requires the data input and authorization process of each level to be carried out digitally. In some cases of assessment, the maturity assessor still considers that an authentic authorization must be in the form of initials or wet signature.

There were several previous studies that review on the maturity assessment of SPIP. The first was research entitled "Implementation of Government Internal Control System (SPIP) In Gorontalo Regency", published by Journal of Research in Accounting and Auditing "Goodwill” Volume 8, Number 2 Year 2017. The second was research entitled "Analysis of the Maturity of the Implementation of Government Internal Control System on BPKP Representatives of West Kalimantan Province", published by the Journal of Accounting Scientific Study of Faculty of Economics UNTAN volume 3. The third was research entitled "Evaluation of Implementation of Government 
Internal Control System (SPIP) at the Department of Agriculture of the Special Region of Yogyakarta" published by the Accounting and Business Information Systems Journal Volume 26. All of the researches above discussed about the maturity level of the implementation of SPIP in several local governments with the results of the research in the form of maturity level from 0 to 5 . However, there is still no research which evaluates the assessment system of SPIP maturity based on the Regulation of the Head (Perka) BPKP Number of 2016.

Based on the analysis of the significance of SPIP implementation, the target maturity specified in the RPJMN, the problem perceived by the local government in the Province of DIY, as well as viewed from the previous research, it is necessary to conduct an evaluation on maturity assessment system of SPIP implemented by BPKP.

This study has 3 objectives. First, it studies the guidelines and the implementation of maturity assessment of SPIP in the Regulation of BPKP Number 4 of 2016. Second, it identifies the constraints and problems. Third, it provides recommendations for improvement. Therefore, this research focuses on assessing whether the assessment instrument set out in the maturity assessment guidelines of SPIP have been able to measure the implementation of SPIP accurately and what problems occurring in the implementation process of SPIP maturity assessment.

\section{Theoretical Framework}

Committee of Sponsoring the Organization of the Treadway Commission (COSO) in Tuanakotta (2019) defines internal control as: "Internal control is a process, effected by an entity's board of directors, management, and other personnel, designed to provide reasonable assurance regarding the achievement of objectives relating to operations, reporting, and compliance". This definition emphasizes that internal control is aimed at achieving objectives in one or several aspects of the company such as operation, reporting, and compliance with the regulations. SPIP is a process and activity that runs in the achievement of objectives implemented by all personnel in an organization.

The definition of internal control system and SPIP is defined in the Government Regulation No. 60 of 2008 that "Internal Control System means integral process in acts and activities performed continuously by leaders and all personnel to provide reasonable assurance of the attainment of the organizational goals through effective and efficient activities, reliable financial statements, state assets safekeeping, and compliance with legislation". SPIP is conducted comprehensively both in central and local governments.
Government Regulation (PP) Number 60 of 2008 also set the goals of SPIP that is to provide reasonable assurance in attainment of the effectiveness and efficiency of the achievement of the government administration objectives, the reliability of the financial statements, the safeguarding of the state asset, and the compliance with the legislation. This goals should become the basis in the implementation of SPIP in any government agency.

SPIP consists of five elements; control environment, risk assessment, control activities, information and communication, internal control monitoring. Each of the five elements has sub-elements. The total of all sub-elements of the five elements are 25 with the details presented in Table II.

TABLE II

ELEMENTS AND SUB-ELEMENTS OF SPIP

\begin{tabular}{|c|c|}
\hline Element & Sub-element \\
\hline $\begin{array}{l}\text { Control } \\
\text { Environment }\end{array}$ & $\begin{array}{l}\text { 1. Upholding integrity and ethical values } \\
\text { 2. Commitment to competency } \\
\text { 3. Conducive leadership } \\
\text { 4. Establishment of organizational structure } \\
\text { as required } \\
\text { 5. Appropriate delegation of authority and } \\
\text { responsibility } \\
\text { 6. Proper policy making and policy } \\
\text { implementation regarding human } \\
\text { resource development } \\
\text { 7. Effective role embodiment of } \\
\text { government internal supervisory } \\
\text { apparatus }\end{array}$ \\
\hline $\begin{array}{l}\text { Risk } \\
\text { assessment }\end{array}$ & $\begin{array}{ll}\text { 1. } & \text { Goal setting } \\
\text { 2. } & \text { Risk assessment } \\
\text { 3. } & \text { Managing risk during changes } \\
\end{array}$ \\
\hline $\begin{array}{l}\text { Control } \\
\text { Activities }\end{array}$ & $\begin{array}{l}\text { 1. Review on the performance of related } \\
\text { Government Institutions } \\
\text { 2. Human resources development } \\
\text { 3. Control on the information system } \\
\text { management } \\
\text { 4. Physical control on assets } \\
\text { 5. Stipulation and reviewing of the } \\
\text { performance indicators } \\
\text { measurement } \\
\text { 6. Separation of functions } \\
\text { 7. Authorization of important transactions } \\
\text { and events } \\
\text { 8. Accurate and timely recording of } \\
\text { transactions and events } \\
\text { 9. Access restriction to the resources and its } \\
\text { recording } \\
\text { 10. Accountability on resources and its } \\
\text { recording } \\
\text { 11. Proper documentation of the Internal } \\
\text { Control System and the important } \\
\text { transactions and events }\end{array}$ \\
\hline $\begin{array}{l}\text { Information and } \\
\text { Communication }\end{array}$ & $\begin{array}{l}\text { 1. Information } \\
\text { 2. Conducting effective communication }\end{array}$ \\
\hline $\begin{array}{l}\text { Supervision and } \\
\text { Monitoring } \\
\end{array}$ & $\begin{array}{ll}\text { 1. } & \text { Continuous monitoring } \\
\text { 2. } & \text { Separated evaluation } \\
\end{array}$ \\
\hline
\end{tabular}

Source: PP No. 60 of 2008

Elements and sub-elements of SPIP are implemented in the operating activities in an integrated manner, and embedded in every business process that is running. Control should be attached to every process of the 
implementation of the program or activity conducted on any part of organization either at the headquarter, division, team, and committee ad hoc.

\section{SPIP Maturity Assessment}

According to IIA (2013) maturity model describes the stages of the process which is believed to be directing at better output and outcomes. Low maturity reflects the low possibility in achieving the goal, while a higher level of maturity reflects higher chance of success.

SPIP maturity is the maturity/complete level of SPIP implementation in achieving the objectives of internal control in accordance with the Government Regulation (PP) No. 60 of 2008. Maturity level of SPIP is a framework which contains the basic characteristics indicating the maturity level of SPIP implementation that is structured and sustainable. The maturity level can be used as an evaluative instrument for the implementation of SPIP conducted by the ministry/ agency/local government (M/A/L) and as the basis and guidelines in planning the improvement of SPIP.

Maturity assessment system of SPIP is set by BPKP with the issuance of the Regulation of the Head of BPKP No. 4 of 2016 on the Assessment Guideline and Strategy of Maturity Improvement of Government Internal Control System. The framework of SPIP maturity in this regulation is patterned in six levels as presented in Table I. The levels are level 0, 1, 2, 3, 4 and 5. Each level of maturity has the basic characteristics which indicates the role or capability of SPIP implementation in supporting the achievement of the objectives of government agencies. Each level of SPIP maturity has the basic properties which can significantly distinguish one level from another, although as a continuous process, it has contiguity. The basic properties can be seen from the general characteristics of each level as shown in Table III.

TABLE III

LEVEL AND CHARACTERISTICS OF SPIP

\begin{tabular}{|c|l|}
\hline Level & \multicolumn{1}{|c|}{ Characteristics of SPIP } \\
\hline 0 & $\begin{array}{l}\text { Institution did not have policies and procedures } \\
\text { that are necessary to carry out the practices of } \\
\text { internal control. }\end{array}$ \\
\hline 1 & $\begin{array}{l}\text { 1. Institution has established written } \\
\text { policies/SOP according to the needs; } \\
\text { 2. The written policies refer to the applicable } \\
\text { laws and regulations; }\end{array}$ \\
\hline 2 & $\begin{array}{l}\text { Institution is required to communicate the } \\
\text { policies/ SOP to all officials and employees and } \\
\text { other interested parties (external); }\end{array}$ \\
\hline 3 & $\begin{array}{l}\text { 1. Policies/SOP has been implemented by most } \\
\text { of the officials and employees; } \\
\text { 2. Evidence of the implementation of the } \\
\text { policies/SOP has been well documented. The } \\
\text { use of application is allowed to support the } \\
\text { implementation and documentation; }\end{array}$ \\
$\begin{array}{l}\text { 3. No problems of control weaknesses that the } \\
\text { BPK and APH investigation results are } \\
\text { associated with the sub-elements of the SPIP. }\end{array}$ \\
\hline 4 \\
$\begin{array}{c}\text { 1. Point level 3 has been implemented in a } \\
\text { sustainable manner; }\end{array}$ \\
\hline Managed
\end{tabular}

\begin{tabular}{|c|c|}
\hline $\begin{array}{c}\text { and } \\
\text { measurable) }\end{array}$ & $\begin{array}{l}\text { 2. Evaluation of the policies/SOP and its } \\
\text { implementation has been conducted } \\
\text { periodically (at least } 2 \text { times), formal, and } \\
\text { documented; } \\
\text { 3. Follow up on the results of evaluation has } \\
\text { been implemented and it results in improved } \\
\text { internal control performance that is indicated } \\
\text { by: } \\
\text { a. The attainment of WTP opinion } \\
\text { (unqualified opinion) on the audit of } \\
\text { financial statements on a recurring basis } \\
\text { at least } 3 \text { times in a row in the last } 5 \text { years; } \\
\text { b. No problems of control weaknesses found } \\
\text { in the Audit Board of the Republic of } \\
\text { Indonesia (BPK) and law enforcement } \\
\text { officers (APH) investigation results; } \\
\text { c. Performance report (LKj) score of M/A/L } \\
\text { minimum BB } \\
\text { d. Capability of Government Internal } \\
\text { Supervisory Apparatus (APIP) level } 3 \\
\text { e. No violation of the law of corruption } \\
\text { which is processed in the court (by } \\
\text { echelon } 2 \text { and above). }\end{array}$ \\
\hline $\begin{array}{c}5 \\
\text { (Optimum) }\end{array}$ & $\begin{array}{l}\text { 1. Points in Level } 4 \text { have been implemented on } \\
\text { an ongoing basis; } \\
\text { 2. Policies/SOP have been improved in a } \\
\text { sustainable manner. } \\
\text { 3. Management systems and policies/SOP } \\
\text { have been integrated and using the } \\
\text { information technology. }\end{array}$ \\
\hline
\end{tabular}

Source: Regulation of the Head of BPKP Number 4 of 2016

The assessment focus of SPIP maturity is a variable used to indicate the maturity level of SPIP implementation. These variables are sub-elements of SPIP in Government Regulation No. 60 of 2008. There are five elements described into 25 sub-elements as the assessment focus as summarized in Table II.

Overall, there are five assessment focuses spread into 25 SPIP sub-elements. In each assessment focus, the achievement of maturity level ( 0 to 5$)$ will be measured, in order to form a matrix of 125 measurement parameters. With the assumption that the assessment focus has a high level of interconnectedness and a different level of importance, then the assessment focus has different weight as presented in Table IV.

\section{TABLE IV}

WEIGHT OF ASSESSMENT FOCUS (SUB-ELEMENTS)

\begin{tabular}{|l|l|c|c|c|}
\hline No. & Element & $\begin{array}{c}\text { Number of } \\
\text { Element } \\
\text { Weight }\end{array}$ & $\begin{array}{c}\text { Number of } \\
\text { Sub-element }\end{array}$ & $\begin{array}{c}\text { Element } \\
\text { Weight }\end{array}$ \\
\hline 1 & Control Environment & 30 & 8 & 3.75 \\
\hline 2 & Risk Assessment & 20 & 2 & 10 \\
\hline 3 & Control Activity & 25 & 11 & 2.25 \\
\hline 4 & $\begin{array}{l}\text { Information and } \\
\text { Communication }\end{array}$ & 10 & 2 & 5 \\
\hline 5 & Monitoring & 15 & 2 & 7.5 \\
\hline & Total & $\mathbf{1 0 0}$ & $\mathbf{2 5}$ & \\
\hline
\end{tabular}

Source: Regulation of the Head of BPKP Number 4 of 2016

To determine the SPIP maturity score, it was used the score of validation results by making a weighted mean of the validation score. These scores were used to determine the SPIP maturity level. The score interval of SPIP maturity level is as listed in Table 1. 


\section{Research Method}

This research used qualitative method. This research described and analyzed the maturity assessment procedures and process of SPIP implementation conducted by BPKP, identified obstacles and problems occurring both in the perspective of the assessor (BPKP) and the party assessed (local government), and provided recommendations for improvement.

The data collected were primary and secondary data. Primary data consisted interviews and focus group discussion (FGD). While the secondary data consisted of the legislation related to SPIP, guidelines related to the SPIP implementation, and guidelines as well as instrument of SPIP maturity assessment.

The primary and secondary data were obtained through interview, focus group discussion (FGD), and documentation. The interview carried out was semi structured interview to one of the Supervisor Coordinators in BPKP of DIY Representative. The FGD was conducted with the Regional Inspectorate of Kulon Progo Regency with several structural officials and several auditors involved in the SPIP maturity assessment team of Kulon Progo Regency in 2019. The FGD was also carried out with the Inspectorate of Yogyakarta City, with one structural official and one auditor involved in SPIP maturity assessment team of Yogyakarta City in 2019. Study and review of documentation were performed on the legislation and guidelines for the SPIP implementation, SPIP maturity assessment guidelines, and the instrument used by the assessor team during the assessment process, such as questionnaires and paper work.

The obtained data were analyzed using interactive model. Interactive model uses 4 main processes, which are; data collection, data reduction, data presentation, and conclusion or verification (Miles and Huberman, 1984., Sugiyono, 2007). Interview and focus group discussion data were in the form of voice recordings written in the form of conversation script. Interview script, FGD script, and notes of the document review results were reduced through codification, then summarized and focused on some of the issues that became the concern of all respondents. The reduced data were then presented (display) in the form of table, matrix, and chart. Display data would be used to describe the situation of the research object and to draw conclusions.

\section{Results and Discussion}

\section{Assessment System of SPIP Maturity}

The assessment system of SPIP maturity for the local government (provincial government, city government, and regency government) consists of three main processes; SPIP maturity assessment process, quality assurance process, and report issuance process of the assessment results as illustrated in Figure 1. SPIP maturity assessment is carried out by the inspectorate of each local government based on the Regulation of the Head of BPKP No. 4 of 2016 on Guidelines and Strategies for Improving SPIP Maturity. While the quality assurance is carried out by the Representative BPKP and BPKP Head Office, and the issuance of the assessment result report is conducted by BPKP Head Office based on the Regulation of the Deputy of BPKP Number 4 of 2017 on Guidelines for Quality Assurance of SPIP Maturity Assessment.

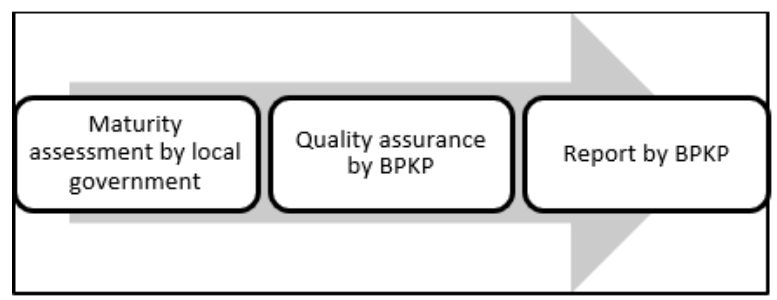

Figure 1: The main process in SPIP maturity assessment system

\section{SPIP Maturity Assessment}

SPIP maturity assessment consists of three stages which are preparation, implementation, and reporting stages. The three stages should be implemented in the maturity assessment process.

The preparation stage consists of five stages, and the first is preparation of assessor team. Each assessor must have a good understanding of SPIP maturity level assessment, i.e. personnel who have attended the related education/socialization/training. In practice, the assessor team is the officials and/or auditors in the local inspectorate. The second is the determination of a work unit or local apparatus organization (OPD) that become the assessment samples. Determination of the assessment sample should consider the risk factors, among others, the amount of total budget, the number of personnel, and the complexity of activities in each OPD. In addition, the selected samples also pay attention to the representation of function characteristics, which are public service function, internal control function, and supporting function such as financial/asset management and personnel. In practice, on the maturity assessment carried out in 2019, BPKP directed that the sample assessment consisting of at least 5 OPDs with the representation of function characteristic as follows: three OPDs of the public service function such as department of education or department of health, one OPD of the supporting function such as the regional planning agency, and one OPD of the internal supervision function which was the inspectorate of the regency/city. The third is the formation of the accompanying team (counterpart). Accompanying team consists of personnel involved in the Task Force (Satgas) of SPIP 
Implementation on each OPD or work unit in OPD serving as the Task Force. The fourth is the determination of the activity plan (action plan) for SPIP maturity assessment, which contains, among others the scope of assignment, period, funding, and working measures. The fifth is initial presentation (entry meeting). Initial presentation aims to form and obtain the equation of perception between the assessor team and the OPD of assessment sample.

The assessment implementation stage consists of preliminary assessment of the maturity level, validation of the preliminary assessment results, testing the maturity evidence, giving the final score of maturity, and preparation of reports on the maturity assessment result. The process of assessment implementation is stipulated in the Regulation of the Head of BPKP Number 4 of 2016 and the Circular Letter of the Deputy of the Head of BPK PPKD Number SE-002/D3/02/2018 on the Technical Explanation of the Parameters to Meet the SPIP Maturity Level.

The preliminary assessment of maturity level was conducted to obtain early information of the maturity level of SPIP implementation in each OPD sample. This preliminary assessment was carried out by filling the perception survey with instrument in the form of questionnaire format that had been provided in the Regulation of the Head of BPKP Number 4 of 2016. This questionnaire contains questions about the matrix of 25 assessment focuses and the achievement of maturity level (0 to 5) which forms 125 measurement parameters with the illustration presented in Table V. The questionnaire was filled by the entire structural officials of OPD samples and a minimum of three structural nonofficial employees by taking into account the number of samples (sample size). Filling the questionnaire can be done individually and through acclamation, an agreement of all respondents to produce an answer.

\section{TABLE V}

\section{EXAMPLES OF QUESTIONS AS QUESTIONNAIRE ILLUSTRATION}

\begin{tabular}{|c|l|c|}
\hline No. & \multicolumn{1}{|c|}{ Question } & Y/N \\
\hline 1. & $\begin{array}{l}\text { Does the organization (Ministry/Agency/Local } \\
\text { Government) have Code of Ethics that is formally } \\
\text { set by the leaders of the organization (the Head of } \\
\text { the Institution for M/A and } \\
\text { Governor/Regent/Mayor to the Local } \\
\text { Government)? }\end{array}$ & \\
\hline 2. & $\begin{array}{l}\text { Does the Code of Ethics of the organization has } \\
\text { been communicated to most of the employees in } \\
\text { your work unit/organizational unit? }\end{array}$ & \\
\hline 3. & $\begin{array}{l}\text { Do the majority of employees in your work } \\
\text { unit/organizational unit behave in accordance } \\
\text { with the Code of Ethics of the organization? }\end{array}$ & \\
\hline 4 & $\begin{array}{l}\text { Do the organizatin leaders monitor / evaluat the } \\
\text { implementation of the Code of Conduct (Code of } \\
\text { Ethics) periodically? }\end{array}$ & \\
\hline 5 & $\begin{array}{l}\text { Is the organization's Code of Conduct developed } \\
\text { continuously, and do the organization's leaders } \\
\text { monitor on the implementation automatically? }\end{array}$ & \\
\hline
\end{tabular}

The questionnaire filled by the respondents then was validated to assess whether the answer was "Consistent" or "Inconsistent". The answers to the statement against any focus that had been made graded in five levels must be ensured consistent. Conditions at a low level must have been fulfilled before the conditions in the next level are filled. That means if the respondents will answer "Yes" (Y) at a higher level, then the level below should be answered "Yes" (Y) first. If the "Yes" (Y) answer is listed on the higher level but the level below is answered "No" (T), then the answer is considered "Inconsistent". The "inconsistent" answer needs to be fixed, i.e. by lowering the value to the level below it.

The respondents' answers which had been validated were used to assess the initial score of SPIP maturity. The answers that had been validated were concluded per indicator in accordance with most (mode) answers so as to produce a temporary value for each indicator in the six levels or equivalent each with level of $0,1,2,3$, 4 and 5. The values of all indicators were summed to produce the initial score of SPIP maturity.

The initial scores of SPIP maturity were tested for validity with the collection of supporting evidence obtained from advanced questionnaires, interviews, document review, or observation. Collection of evidence supporting the SPIP maturity survey was specifically aimed to validate the answers of SPIP maturity perception survey. Of the result of SPIP maturity perception survey that were "Consistent", it was continued with the collection of maturity evidence through sampling both on respondents and survey answers. As for the "Inconsistent" survey results, the collection of evidence was conducted through sampling on respondents and all questionnaire answers (census). Due to many parameters of 125 parameters, the selection of parameters that became the sample was determined by the assessor team with professional judgment. As for the detailed focus/indicators, parameter, and parameter measurement, they are specified in the Circular Letter of the Deputy of the Head of BPK PPKD Number SE-002/D3/02/2018 on the Explanation of the Technical Parameters to Meet the SPIP Maturity Level. Testing supporting evidence also used the consistency principle, the fulfillment of evidence of a maturity level must be completely fulfilled to enable the assessment to the next level.

The results of testing the evidence supporting SPIP maturity were used to give the final score of maturity. A score was given for each focus/indicator so as to produce the score of indicator maturity level. The indicator maturity level scores are accumulated by taking into account the weight of each indicator (weight of sub-elements or focus) as presented in Table IV. Total score of all indicators, 25 indicators, are accumulated so as to produce a SPIP maturity score for each OPD sample based on the interval score of 
maturity level as presented in Table 1 . The score values of all indicators of all OPD samples are accumulated to produce the SPIP maturity score for the local government.

The final stage of maturity assessment which is carried out by the assessor team of SPIP maturity of the local government is the preparation of assessment result report. The report is organized by presenting, among others, area of improvement on each of the assessment focus and recommendations for the head of region in order to improve the SPIP maturity level in the future. The report of SPIP maturity assessment results is published with the signature of the regional secretary.

\section{Quality Assurance}

Quality assurance aims to assess whether the entire SPIP maturity assessment process performed by the local government assessor has been carried out in accordance with the provisions in the Regulation of the Head of BPKP Number 4 of 2016. The SPIP maturity assessment process consists of preparation, assessment, and reporting stages.

The quality assurance process is conducted with six stages. First, local government performs independent assessment of SPIP maturity based on the Regulation of the Head of BPKP Number 4 of 2016. Second, the local government publishes the report of SPIP maturity assessment results and presents it to BPKP Representatives. Third, if the results of independent assessment carried out by the local government obtain a score less than 3.00, then the BPKP Representatives will conduct the quality assessment of the report of independent assessment results. Furthermore, if based on the quality assurance process by the BPKP Representatives, the score obtained from SPIP maturity assessment result is still less than 3.00, then the BPKP Representatives prepare reports on the quality assurance results with a cover letter signed by the Deputy for the Supervision of Regional Financial Implementation (PPKD). Fourth, if the results of the SPIP maturity independent assessment carried out by the local government obtain a score equal to or greater than 3.00, then the quality assurance process is conducted by a team appointed by the Deputy of PPKD Fifth, the team performs quality assurance and the results are presented in the form of reports after exposure to the Deputy of PPKD. If the score of SPIP maturity after going through the quality assurance process remains the same or higher than 3.00, then the Deputy of PPKD will include the Award for the local government. Sixth, the Deputy of PPKD submits a report quality assurance along with a cover letter and the award to the local government through the BPKP Representatives.

\section{The Use of Management Information System}

The assessment process of SPIP maturity level is quite complex because it involves 125 indicators. The complexity is higher when implemented with the large number of respondents and sample units. Therefore, BPKP provides Management Information System of SPIP Maturity Assessment (SINIMA SPIP) which is intended to accelerate and simplify the assessment process of SPIP maturity level and guarantee the quality.

SINIMA SPIP was built based on the Regulation of the Head of BPKP Number 4 of 2016 which is designated for the local governments for assessment process of SPIP maturity and for BPKP for the quality assurance process as illustrated in figure 4 . Therefore, this system also applies the consistency principle, where the fulfillment of evidence a maturity level must be completely fulfilled to enable the assessment to the next level. If an OPD as the respondent has not been able to meet all the evidence and documents that are required in the parameters at one level, then the system will not open the access for the input of evidence and documents to the next level.

\section{Evaluation of SPIP Maturity Assessment System}

Evaluation of the SPIP maturity assessment system reviews two aspects that become the concern of BPKP and local government, which are the rule and implementation aspects. Rule aspect reviews the evaluation of the substance of the Regulation of the Head of BPKP number 4 of 2016. While the implementation aspect reviews the constraints faced by local governments in the SPIP maturity assessment process. The following will review both aspects.

First, the Regulation of Head of BPKP number 4 of 2016 does not direct the assessor team and quality assurance team to study and assess the relationship between assessment indicators (sub-elements of SPIP). The Regulation of Head of BPKP sets the assessment on 25 assessment indicators with each of the 5 parameters of maturity level assessment ( 0 to 5 ) to form 125 assessment parameters with illustrations presented in Table V. However, the Regulation of Head of BPKP does not set the assessment or review of the relationship between the assessment indicators, even though the SPIP elements have a relationship to each other. Government Regulation No. 60 of 2008 defines the internal control system as an integral process on the actions and activities carried out continuously by the leaders and all employees to provide reasonable assurance over the achievement of organizational goals.

The integral process on the actions and activities mentioned in SPIP as Government Regulation No. 60 of 2008 is reflected in the relationship between the elements inside. Internal control in SPIP is based on risk. The risk assessment (the second element) aims to identify risk and assess the impact as well as its probability. These risks are controlled with hard 
control in the form of control activities (the third element) and soft control in the form of control over the organization environment (the first element). To oversee the implementation of these three elements, monitoring is performed (the fifth element). For effective process of risk assessment, hard control, soft control, and monitoring, it is necessary to have an adequate information and communication system (the fourth element).

In practice, BPKP has analyzed the relationship between the indicators in SPIP and between SPIP indicators and other governance indicators. In the quality assurance process, BPKP performs the analysis of the relationship between risk assessment indicators and indicators on control activities. This is carried out because control activities should be conducted based on the existing risks. In addition, BPKP also analyzes the relationship between SPIP indicators and other governance indicators such as Performance Accountability System of Government Agency (SAKIP).

Second, the maturity assessment system that requires the fulfillment of evidence in sequence from level one to the level above will complicate the fulfillment by the government. For example, the local government has set a policy/rules/SOP (level 1) and has been implementing the policy/rules/SOP (level 3) but does not have documentation of the activities/socialization (level 2). The final result of this assessment is level 2 because it is considered impossible for a policy to be implemented if it is not properly familiarized. Local governments have difficulty in collecting required evidence because some of the evidence are hard to find and are not even found as they are not archived. This makes the local governments feel the SPIP maturity assessment process emphasizes more on the completeness of administration evidence rather than the substance of the assessment.

\section{Conclusion}

This research concluded that the maturity assessment system contained in the Regulation of the Head of BPKP No.4 of 2016 did not direct the assessor team and the quality assurance team to perform the analysis of the relationship between the indicators in SPIP and between SPIP indicators and other governance indicators. In addition, the implementation of the maturity assessment carried out by the assessment team and local governments faces difficulties in fulfilling the required evidence, this is because the assessment system requires the fulfillment of evidence in order from level one to levels above and also limitation of local governments in fulfillment of evidences. Consequently, they thought that the assessment emphasized more on the completeness of administration evidence rather than the substance of the assessment. Therefore, we recommend that BPKP revises the Regulation of the Head of BPKP No.4 of 2016 to consider two factors. The first is to redirect the assessor team and the quality assurance team to perform the analysis of the relationship between the indicators in SPIP and between SPIP indicators and other governance indicators. The second is to facilitate the assessment process by not focusing on the fulfillment of evidence but the achievement of the substance. This can be done if the first recommendation above is carried out.

\section{References}

A. Irawan, T. 2015. Analisis atas Maturitas Penyelenggaraan Sistem Pengendalian Intern Pemerintah pada Perwakilan BPKP Provinsi Kalimantan Barat. Jurnal Kajian Ilmiah Akuntansi Fakultas Ekonomi UNTAN 3(4).

B. Miles, M.B., dan Huberman, M.A. 1984. Qualitative Data Analysis; A Sourccebook of New Method. London: Beverly hills, Sage Publications.

C. Mukhlis, dan Supriyadi. 2018. Desain Sistem Manajemen Risiko Pada Perguruan Tinggi Badan Hukum (PTN BH) Studi Kasus pada Universitas Gadjah Mada. Journal of Applied Accounting and Taxation, 3(2), 158-167. https://doi.org/10.30871/jaat.v3i2.875

D. Mulyanto, U., dan Halim A. 2019, Evaluasi Penyelenggaraan Sistem Pengendalian Intern Pemerintah (SPIP) Pada Dinas Pertanian Daerah Istimewa Yogyakarta, Accounting and Bussiness Information Systems Journal 26.

E. Paneo, F., Sondakh, J.J., dan Morasa, J. 2017. Penerapan Sistem Pengendalian Intern Pemerintah (SPIP) Pada Kabupaten Gorontalo, Jurnal Riset Akuntansi Dan Auditing "Goodwill" $8: 2$. https://doi.org/10.35800/jjs.v8i2.18132

F. Sugiyono. 2007. Memahami Penelitian Kualitatif. Bandung, Alfabeta.

G. Tuanakotta, TM. 2019. Audit Internal Berbasis Risiko. Penerbit Salemba Empat, Jakarta.

H. Peraturan Pemerintah Nomor 60 Tahun 2008 tentang Sistem Pengendalian Intern Pemerintah.

I. Peraturan Kepala BPKP PER-1326/K/2009 tentang Pedoman Teknis Penyelenggaraan SPIP.

J. Peraturan Kepala BPKP PER-500/K/2010 tentang Pedoman Pemetaan Terhadap Penerapan Sistem Pengendalian Intern Pemerintah (SPIP) di Lingkungan Instansi Pemerintah. 
K. Peraturan Kepala BPKP Nomor PER-852/K/2011 tentang Pedoman Monitoring Perbaikan Sistem Pengendalian Intern di Lingkungan Instansi Pemerintah.

L. Peraturan Kepala BPKP Nomor PER-689/K/D4/2012 tentang Pedoman Pelaksanaan Penyelenggaraan Kegiatan Pengendalian di Lingkungan Instansi Pemerintah.

M. Peraturan Kepala BPKP Nomor PER-688/K/D4/2012 tanggal 25 Mei 2012 tentang Pedoman Pelaksanaan Penilaian Risiko di Lingkungan Instansi Pemerintah.

N. Peraturan Kepala BPKP Nomor PER-687/K/D4/2012 tentang Pedoman
Penyusunan Desain Penyeelenggaraan Sistem Pengendalian Intern Pemerintah.

O. Peraturan Kepala BPKP Nomor 20 Tahun 2013 tentang Pedoman Evaluasi SPIP.

P. Peraturan Kepala BPKP Nomor 4 Tahun 2016 tentang Pedoman Penilaian dan Strategi Peningkatan Maturitas SPIP.

Q. Perdep BPKP Nomor 4 tahun 2017 tentang Pedoman Penjaminan Kualitas Penilaian Maturitas SPIP.

R. Rencana Pembangunan Jangka Menengah Nasional (RPJMN) Tahun 2015-2019.

S. Rencana Pembangunan Jangka Menengah Nasional (RPJMN) Tahun 2020-2024. 